\title{
The effect of online learning on students' understanding of football learning during the Covid-19 pandemic
}

\author{
Komarudin*, Rizka Prihandana Nugraha \\ Pendidikan Jasmani Kesehatan dan Rekreasi Fakultas Ilmu Keolahragaan, Universitas Negeri Yogyakarta, Jl. \\ Colombo No. 1, Karangmalang, Depok, Sleman, Daerah Istimewa Yogyakarta, Indonesia. \\ Corresponding author: komarudin@uny.ac.id
}

\begin{abstract}
This study aims to determine the effect of online learning on students' understanding of football material during the COVID-19 pandemic. The type of research used is quantitative research with an associative approach, research that seeks a causal relationship between one variable $X$ and variable $Y$. The data collection technique used in this study is a survey method with instruments in the form of questionnaires and multiple-choice tests. The subjects in this study were students of Aisyiyah Fullday Wedi Junior High School class VIII, Klaten Regency, Central Java Province amounting to 87 people who were determined using the Total Sampling technique. The data analysis technique used in this study is to use statistics with the F test and Product Moment. The results of the study indicate that there is an effect of online learning on students' understanding of football material at Junior High School Aisyiyah Fullday Wedi, Klaten Regency, Central Java Province during the Covid-19 pandemic. This can be seen from the simple linear regression equation $Y=9.610+0.413 X$ and the close relationship between $X$ variable (online learning) and $Y$ variable (understanding football material) which is 0.694 so it is included in the level of a strong relationship. And the contribution (donations) that exist in the $X$ variable to the $Y$ variable is $4.82 \%$ while $95.18 \%$ is influenced by other variables. From these results, it can be seen that there is an increase or decrease in students' understanding of football material, one of which is influenced by Online Learning at Aisyiyah Fullday Wedi Junior High School, Klaten Regency, Central Java Province. Keywords: Online Learning, Understanding, Football, Covid-19 Pandemic
\end{abstract}

\section{Pengaruh pembelajaran daring terhadap pemahaman materi sepakbola peserta didik pada masa pandemi Covid-19}

\begin{abstract}
Abstrak
Penelitian ini bertujuan untuk mengetahui pengaruh pembelajaran daring terhadap pemahaman materi sepakbola pada peserta didik pada masa pandemi coovid-19. Jenis penelitian yang digunakan adalah penelitian kuantitatif dengan pendekatan asosiatif, penelitian yang mencari hubungan sebab akibat antara satu variabel $\mathrm{X}$ dengan variabel $\mathrm{Y}$. Teknik pengumpulan data yang digunakan dalam penelitian ini yaitu metode survei dengan instrumen yang berupa angket dan tes soal pilihan ganda. Subjek dalam penelitian ini adalah peserta didik Sekolah Menengah Pertama Aisyiyah Fullday Wedi, Kabupaten Klaten, Provinsi Jawa Tengah kelas VIII yang berjumlah 87 orang yang ditetapkan menggunakan teknik Total Sampling. Teknik analisis data yang digunakan dalam penelitian ini adalah dengan menggunakan statistik dengan uji F dan Product Moment. Dari hasil penelitian menunjukkan bahwa terdapat pengaruh pembelajaran daring terhadap pemahaman materi sepakbola peserta didik di Sekolah Menengah Pertama Aisyiyah Fullday Wedi, Kabupaten Klaten, Provinsi Jawa Tengah pada masa pandemi Covid19. Hal ini dapat dilihat dari persamaan regresi linier sederhana $Y=9,610+0,413 X$ dan keeratan hubungan variabel $\mathrm{X}$ (pembelajaran daring) terhadap variabel $\mathrm{Y}$ (pemahaman materi sepakbola) yaitu sebesar 0,694 sehingga termasuk dalam tingkat hubungan yang kuat. Serta Kontribusi (sumbangan) yang ada pada variabel $\mathrm{X}$ terhadap variabel $\mathrm{Y}$ sebesar 4,82\% sedangkan 95,18\% dipengaruhi oleh variabel lain. Dari hasil tersebut terlihat meningkat atau menurunnya pemahaman peserta didik pada materi sepakbola salah satunya dipengaruhi oleh Pembelajaran Daring di Sekolah Menengah Pertama Aisyiyah Fullday Wedi, Kabupaten Klaten, Provinsi Jawa Tengah.

Kata kunci : Pembelajaran Daring, Pemahaman, Sepakbola, Pandemi Covid-19.
\end{abstract}




\section{PENDAHULUAN}

Pendidikan berperan penting dalam proses pembangunan nasional dan kemajuan bangsa. Adanya pendidikan dapat mencerdaskan generasi muda dan mampu mengembangkan potensi diri. Selain itu, pendidikan juga dapat melatih seseorang dalam berpikir kritis dan dinamis, belajar bertanggung jawab, berakhlak mulia, beriman dan bertaqwa kepada Tuhan Yang Maha Esa. Pendidikan diharapkan mampu melahirkan generasi penerus bangsa yang berkompeten, kritis, kreatif, rasional dan mandiri serta berpegang kepada nilai agama. Pendidikan mampu menghasilkan sumber daya manusia yang berkualitas, berpengetahuan luas dan memiliki keterampilan.

Menurut Undang-Undang No 20 Tahun 2003 tentang Sistem Pendidikan Nasional Pendidikan merupakan usaha yang dilakukan secara sadar dan terstruktur dalam rangka mewujudkan suasana belajar dan proses pembelajaran kepada peserta didik agar dapat aktif mengembangkan potensi sebagai kekuatan spriritual keagamaan, pengendalian diri, kepribadian, kecerdasan, berakhlak mulia serta keterampilan demi kemajuan diri sendiri, masyarakat, bangsa dan negara. Pendidikan berfungsi sebagai persiapan yang dilakukan oleh peserta didik menjadi tenaga kerja yang berkualitas yang siap turun kedalam dunia kerja.

Sekolah adalah suatu lembaga yang memberikan layanan berupa pendidikan, proses belajar dan mengajar, (Nasrulloh et al., 2021). Proses belajar mengajar merupakan rangkaian kegiatan dalam ruang lingkup pendidikan. Proses belajar mengajar merupakan suatu kegiatan pembelajaran yang dilakukan berdasarkan kurikulum pada lembaga pendidikan. Proses ini bertujuan untuk membentuk tingkah laku intelektual, moral maupun sosial kepada peserta didik. Demi tercapainya tujuan proses pembelajaran, para peserta didik dalam lingkungan belajar diatur oleh seorang pendidik yang berkompeten dalam bidangnya melalui proses pembelajaran.

Namun, proses pembelajaran peserta didik saat ini terganggu karena adanya ancaman Pandemi Covid 19. Pandemi Covid 19 yang melanda belahan dunia memberikan pengaruh negatif dalam berbagai bidang, tidak terkecuali bidang pendidikan. Pandemi Covid 19 berpengaruh terhadap penyelenggaraan pendidikan di semua jenjang pendidikan. Semakin meningkatnya penyebaran wabah Covid 19 di Indonesia mengakibatkan semua aktifitas dilakukan di rumah demi meminimalisir penyebaran Covid 19.

Menteri Pendidikan dan Kebudayaan Republik Indonesia pada tanggal 24 Maret 2020 mengeluarkan Surat Edaran Nomor 4 Tahun 2020 tentang pelaksanaan kebijakan dalam masa darurat Covid 19. Surat tersebut menyatakan bahwa seluruh proses pembelajaran untuk semua jenjang pendidikan dilaksanakan dirumah melalui media pembelajaran daring yang bertujuan untuk memutus rantai penyebaran Covid 19. Pandemi Covid-19 yang terjadi saat ini menjadikan penghalang untuk melakukan pembelajaran di sekolah sehingga dialihkan menjadi e-learning, (Gusdernawati et al., 2021, Festiawan et al, 2021). Pembelajaran daring dilaksanakan dengan memanfaatkan jaringan internet dalam proses pembelajaran. Dalam pembelajaran daring siswa akan berinteraksi dengan pendidik melalui beberapa aplikasi, seperti classroom, video converence, live chat, zoom dan whatsapp group. Pembelajaran tersebut merupakan inovasi yang dilakukan dalam menjawab tantangan atas ketersediaannya sumber belajar yang lebih variatif (Nakayama dan Yamamoto, 2007).

Pembelajaran daring secara online terlihat mudah dan efektif, namun tidak memiliki aspek psikomotorik di dalam penerapannya. Seperti pada mata pelajaran Pendidikan Jasmani, Olahraga dan Kesehatan yang didominasi oleh aspek psikomotorik. Pendidikan jasmani merupakan suatu proses pembelajaran melalui aktivitas jasmani guna meningkatkan kebugaran jasmani, mengembangkan keterampilan motorik, pengetahuan dan perilaku hidup sehat, kecerdasan emosi serta memiliki sikap sportif. Pendidikan jasmani dilakukan melalui gerakan dan dilaksanakan secara tepat agar dapat memberikan perhatian yang proporsional terhadap kemajuan psikomotor, kognitif dan afektif peserta didik. 


\section{MEDIKORA, Vol. 20 No. 2 Oktober 2021 - 145}

Komarudin, Rizka Prihandana Nugraha

Materi sepakbola mata pelajaran Pendidikan Jasmani, Olahraga dan Kesehatan merupakan salah satu materi yang didominasi dengan kegiatan praktik dilapangan yang melibatkan aktivitas fisik dan sedikit teori. Pendidikan Jasmani, Olahraga dan Kesehatan merupakan sistem pendidikan yang dilakukan menggunakan perintah dengan berbagai tugas yang diberikan, praktik dan sedikit teori (Supriyadi, 2018). Keterbatasan dalam melakukan pembelajaran Pendidikan Jasmani, Olahraga dan Kesehatan secara daring seperti akses internet dan kemampuan operasional terhadap fitur online menjadi hambatan tersendiri dalam melakukan pembelajaran saat Pandemi Covid 19.

Pembelajaran materi sepakbola mata pelajaran Pendidikan Jasmani, Olahraga dan Kesehatan yang dilakukan oleh guru Pendidikan Jasmani, Olahraga dan Kesehatan di Sekolah Menengah Pertama Aisyiyah Fullday Wedi, Kabupaten Klaten, Provinsi Jawa Tengah belum terlaksana dengan baik. Pembelajaran yang seharusnya dilakukan dengan praktik, kini hanya berupa penyampaian materi membuat peserta didik memahami isi materi sepakbola mata pelajaran Pendidikan Jasmani, Olahraga dan Kesehatan. Pembelajaran daring yang dilakukan saat ini membuat peserta didik kesulitan dalam mengaplikasikan secara langsung penjelasan yang diberikan oleh guru karena keterbatasan ruang gerak.

Proses pembelajaran peserta didik pada tahun 2020 hingga jurnal ini ditulis, terganggu karena adanya Pandemi Covid 19. Pandemi Covid 19 yang melanda belahan dunia memberikan pengaruh negatif dalam berbagai bidang, tidak terkecuali bidang pendidikan. Pandemi Covid 19 berpengaruh terhadap penyelenggaraan pendidikan di semua jenjang pendidikan. Semakin meningkatnya penyebaran wabah Covid 19 di Indonesia mengakibatkan semua aktifitas dilakukan di rumah demi meminimalisir penyebaran Covid 19.

Pembelajaran materi sepakbola mata pelajaran Pendidikan Jasmani, Olahraga dan Kesehatan pada dasarnya dilakukan untuk menunjang aspek psikomotor pada peserta didik. Berdasarkan studi pendahuluan yang dilakukan oleh peneliti dengan mengadakan observasi dan wawancara kepada guru dan beberapa peserta didik diperoleh suatu kondisi dimana pembelajaran materi sepakbola mata pelajaran Pendidikan Jasmani, Olahraga dan Kesehatan yang dilakukan pada Sekolah Menengah Pertama Aisyiyah Fullday Wedi, Kabupaten Klaten, Provinsi Jawa Tengah hanya dilakukan via daring dengan memanfaatkan Whatsapp Group. Pemberian materi dan tugas dikirimkan melalui Whatsapp Group, sehingga tidak ada interaksi antara peserta didik dan guru dalam menjalani pembelajaran materi sepakbola mata pelajaran Pendidikan Jasmani, Olahraga dan Kesehatan. Guru seakan mengangap semua mata pelajaran yang dilakukan via daring hanya sebatas pemberian materi dan tugas, namun tidak bagi mata pelajaran Pendidikan Jasmani, Olahraga dan Kesehatan yang memerlukan praktik langsung untuk meningkatkan aspek psikomotorik pada peserta didik. Para pendidik tidak memberikan materi secara spesifik, sehingga para siswa kurang memahami bahkan ada peserta didik yang tidak memahami materi yang diberikan.

Selain itu, dalam pembelajaran daring materi sepakbola mata pelajaran Pendidikan Jasmani, Olahraga dan Kesehatan, pendidik cenderung memberikan penjelasan tentang materi namun tidak dapat diaplikasikan secara langsung. Kurang efektifnya pembelajaran materi sepakbola mata pelajaran Pendidikan Jasmani, Olahraga dan Kesehatan yang hanya memberikan penjelasan tanpa adanya praktik langsung di lapangan membuat peserta didik kurang memahami materi yang diberikan oleh guru Pendidikan Jasmani, Olahraga dan Kesehatan. Pemahaman materi yang disampaikan oleh guru akan efektif kepada peserta didik apabila disertai dengan penerapan dalam dunia nyata. Beradasarkan latar belakang tersebut maka penulis tertarik untuk melakukan penelitian tentang Pengaruh Pembelajaran Daring Terhadap Pemahaman materi sepakbola mata pelajaran Pendidikan Jasmani, Olahraga dan Kesehatan Peserta Didik Sekolah Menengah Pertama Aisyiah Fullday Wedi, Kabupaten Klaten, Provinsi Jawa Tengah Pada Masa Pandemi Covid 19. 


\section{METODE}

Penelitian ini menggunakan pendekatan kuantitatif dengan metode analisis regresi sederhana. Menurut Sugiyono (2016: 8) metode penelitian kuantitatif dapat diartikan sebagai metode penelitian yang berlandaskan pada filsafat positif, digunakan untuk meneliti pada populasi atau sampel tertentu, pengumpulan data menggunakan instrumen penelitian, analisis data bersifat kuantitatif atau statistik, dengan tujuan untuk menguji hipotesis yang telah ditetapkan. Metode pengambilan data yang digunakan dalam penelitian ini adalah survei dan tes.

Penelitian ini dilakukan di Sekolah Menengah Pertama Aisyiyah Fullday Wedi yang berlokasi di Kecamatan Wedi Kabupaten Klaten Provinsi Jawa Tengah. Waktu penelitian dilakukan pada bulan Februari 2021 sampai dengan Maret 2021. Populasi dalam penelitian ini adalah seluruh peserta didik kelas VIII Sekolah Menengah Pertama Aisyiyah Fullday Wedi, Kabupaten Klaten, Provinsi Jawa Tengah yang berjumlah 87 siswa. Jumlah tersebut terbagi ke dalam tiga kelas VIII A, VIII B, dan VIII C. Masing-masing kelas memiliki 29 siswa.

Teknik pengumpulan data dalam penelitian ini dengan metode kuesioner dan tes. Metode kuesioner dilakukan menggunakan pertanyaan tertulis untuk memperoleh informasi dalam penelitian. Penyebaran kuesioner menggunakan google form yang disebarkan kepada responden yaitu siswa dan siswi Sekolah Menengah Pertama Aisyiyah Fullday Wedi, Kabupaten Klaten, provinsi Jawa Tengah. Respon atas setiap butir pertanyaan diberikan skor atau nilai berdasarkan Skala Likert. Skala Likert merupakan suatu penilaian yang digunakan untuk mengukur sikap, pendapat dan persepsi seseorang atas fenomena yang terjadi (Sugiyono, $2016: 93$ ).

Tabel 1. Indikator Pengukuran Skala Likert

\begin{tabular}{cc}
\hline Indikator Jawaban & Rating \\
\hline Sangat Setuju (SS) & 4 \\
Setuju (S) & 3 \\
Tidak Setuju (TS) & 2 \\
Sangat Tidak Setuju (STS) & 1 \\
\hline
\end{tabular}

Tes yang dilakukan dalam penelitian ini merupakan tes tertulis menggunakan soal pilihan ganda untuk mendapatkan hasil belajar siswa pada materi sepakbola mata pelajaran Pendidikan Jasmani Olahraga dan Kesehatan siswa dan siswa Sekolah Menengah Pertama Aisyiah Fullday Wedi, Kabupaten Klaten, Provinsi Jawa Tengah. Pemberian tes bertujuan untuk melihat pemahaman materi sepakbola pada mata pelajaran Pendidikan Jasmani Olahraga dan Kesehatan siswa dan siswa Sekolah Menengah Pertama Aisyiah Fullday Wedi, Kabupaten Klaten, Provinsi Jawa Tengah yang dilaksanakan secara daring.

Analisis data dalam penelitian ini menggunakan analisis data kuantitatif. Analisis data kuantitatif dalam penelitian ini terdiri dari analisis statistik deskriptif, uji instrument, analisis regresi linear sederhana dan uji hipotesis.

Model regresi linear sederhana digunakan untuk menguji hipotesis pertama dan hipotesis kedua dalam penelitian yang dituliskan sebagai berikut (Sugiyono, $2014: 270$ ) : Y = a + bX Keterangan : Y : variabel dependen yaitu tingkat pemahaman siswa pada materi sepakbola pada mata pelajaran Pendidikan Jasmani Olahraga dan Kesehatan X : variabel independent yaitu pembelajaran materi sepakbola pada mata pelajaran Pendidikan Jasmani Olahraga dan Kesehatan secara daring a : konstanta sebarang dari variabel Y jika variabel $\mathrm{X}$ bernilai konstan $\mathrm{b}$ : koefisien regresi yang menunjukkan penurunan atau kenaikan pada variabel independen.

\section{HASIL DAN PEMBAHASAN}

Hasil penelitian ini dimaksudkan untuk mengetahui pengaruh pembelajaran daring terhadap pemahaman materi sepakbola pada mata pelajaran Pendidikan Jasmani Olahraga dan Kesehatan peserta didik Sekolah Menengah Pertama Aisyiyah Fullday. Penelitian ini dilaksanakan pada bulan Februari-Maret 2021 di Sekolah Menengah Pertama Aisyiyah Fullday 
Wedi, Kabupaten Klaten pada kelas VIII dengan sampel 87 peserta didik. Hasil analisis disajikan sebagai berikut:

1. Deskripsi Variabel Penelitian

Deskripsi data berikut ini berisi informasi data meliputi mean, median, modus, standar deviasi, simpangan baku dan distribusi frekuensi masing-masing variabel penelitian. Penentuan tabel distribusi frekuensi dilakukan dengan melakukan perhitungan kelas interval, sebaran data dan panjang kelas.

a. Deskripsi Pembelajaran Daring

Data variabel pembelajaran daring diperoleh dari kuesioner yang disebarkankepada responden dengan 22 butir pertanyaan. Kuesioner tersebut disusun menggunakan Skala Likert yang dimodifikasi dengan 4 skor alternatif jawaban. Dengan analisis menggunakan bantuan SPSS 25.0 skor terendah adalah 43, skor tertinggi adalah 72, ratarata (mean) 55,87, nilai tengah (median) 56, modus 54, dan standar deviasi sebesar 4,28. Hasil selengkapnya dapat dilihat pada tabel sebagai berikut:

Tabel 2. Deskriptif Statistik Pembelajaran Daring

\begin{tabular}{lr}
\hline \multicolumn{2}{c}{ PEMBELAJARAN DARING } \\
\hline Mean & 55,87356322 \\
Median & 56 \\
Mode & 54 \\
Standard Deviation & 4,222874029 \\
Range & 29 \\
Minimum & 43 \\
Maximum & 72 \\
Sum & 4861 \\
\hline$N$ & 87 \\
\hline
\end{tabular}

b. Pemahaman Materi Sepakbola pelajaran Pendidikan Jasmani Olahraga dan Kesehatan

Data variabel pemahaman materi sepakbola pada mata pelajaran Pendidikan Jasmani Olahraga dan Kesehatan diperoleh dari instrument tes yang telah dikerjakan responden dengan jumlah 20 butir soaldengan 4 pilihan jawaban. Skor yang diberikan jika menjawab benar adalah1 dan jika salah 0 . Hal ini berarti skor ideal terendah adalah 0 dan skor idealtertinggi 20. Setelah dilakukan uji validitas didapatkan skor terendah 6 danskor tertinggi 19. Dari hasil analisis statistik menggunakan program SPSS 25.0 diperoleh skor terendah adalah 7 skor tertinggi adalah 19 rata-rata (mean) 13,6, nilai tengah (median) 14, modus 14, dan standar deviasi sebesar 2,56. Hasil selengkapnya dapat dilihat pada tabel sebagai berikut:

Tabel 3. Deskriptif Statistik Pemahaman Materi Sepakbola pada mata pelajaran Pendidikan Jasmani Olahraga dan Kesehatan

\begin{tabular}{lr}
\hline \multicolumn{2}{c}{ Pemahaman Materi Sepakbola } \\
\hline Mean & 13,63218391 \\
Median & 14 \\
Mode & 14 \\
Standard Deviation & 2,561408327 \\
Range & 12 \\
Minimum & 7 \\
Maximum & 19 \\
Sum & 1186 \\
\hline$N$ & 87 \\
\hline
\end{tabular}




\section{MEDIKORA, Vol. 20 No. 2 Oktober 2021 - 148}

Komarudin, Rizka Prihandana Nugraha

2. Uji Prasyarat Analisis

a. Uji Normalitas

Uji normalitas bertujuan untuk mengetahui sebaran data dari masing- masing variabel penelitian berdistribusi normal atau tidak, selanjutnya dapatdigunakan metode statistika yang akan digunakan apakah menggunakan statistic parametris atau nonparametris. Uji normalitas dalam penelitian ini menggunakan Kolmogorov Smirnov. Apabila nilai hitung kurang dari taraf signifikansi 5\% maka data tersebut tidak berdistribusi normal. Hasil pengujian nornalitas dapat dilihat pada tabel sebagai berikut:

Tabel 4. Uji Normalitas

\begin{tabular}{|c|c|c|c|c|}
\hline \multirow{3}{*}{$\begin{array}{c}\mathrm{N} \\
\mathrm{O}\end{array}$} & \multirow{3}{*}{ Variabel } & \multicolumn{3}{|c|}{ Taraf } \\
\hline & & Sig & & Keterangan \\
\hline & & & $\begin{array}{c}\text { Signifikans } \\
\mathrm{i}\end{array}$ & \\
\hline 1 & Pembelajaran Daring & 0,56 & 0,05 & Normal \\
\hline 2 & $\begin{array}{l}\text { Pemahaman materi } \\
\text { sepakbola Mata }\end{array}$ & 0,08 & 0,05 & Normal \\
\hline & Pelajaran Pendidikan & & & \\
\hline & Jasmani Olahraga & & & \\
\hline & dan Kesehatan & & & \\
\hline
\end{tabular}

Berdasarkan hasil tabel di atas, diketahui bahwa nilai Asymp Sig variabel pembelajaran daring $(\mathrm{X})$ sebesar 0,56, variabel pemahaman materi sepakbola Mata Pelajaran Pendidikan Jasmani Olahraga dan Kesehatan (Y) sebesar 0,08. Hal tersebut menunjukkan nilai Asymp Sig kedua variabel lebih besar dari 0,05 sehingga data variabel penelitian dapat dikatakan berdistribusi normal.

\section{b. Uji Linearitas}

Uji linearitas bertujuan untuk mengetahui sebaran data antara variabel bebas dan terikat linear atau tidak. Untuk menentukan linearitas adalah dengan cara melihat nilai Sig. pada Deviation from Liniarity di Annova Table. Apabila nilai lebih dari 0,05 maka bersifat linear sehingga dapat disimpulkan memenuhi syarat linearitas. Hasil Uji Linearitas dapat dilihat pada tabel dibawah ini.

Tabel 5. Uji Linearitas

\begin{tabular}{llccc}
\hline No & Variabel & $\begin{array}{l}\text { Sig Deviation } \\
\text { from } \\
\text { Liniarity }\end{array}$ & $\begin{array}{c}\text { Taraf } \\
\text { Signifikans } \\
\text { i }\end{array}$ & Keterangan \\
\hline 1 & $\begin{array}{l}\text { Pembelajaran } \\
\text { Daring dengan } \\
\text { Pemahaman } \\
\text { Materi Sepakbola }\end{array}$ & 0,50 & 0,05 & Liniar \\
\hline
\end{tabular}

Berdasarkan hasil tabel di atas terbukti bahwa Deviation from Liniarity antara variabel bebas dengan terikatnya adalah lebih besar terhadap taraf signifikansinya $(0,50>0,05)$. Dengan demikian, seluruh variabel dalam penelitian ini memenuhi syarat linieritas dan data variabel dapat dikatakan bersifat linier.

\section{Pengujian Hipotesis}

a. Analisis Regresi Sederhana

Pengujian hipotesis dalam penelitian ini bertujuan untuk membuktikan pengaruh pembelajaran daring terhadap pemahaman materi sepakbola Mata Pelajaran Pendidikan 
Jasmani Olahraga dan Kesehatan pada peserta didik di Sekolah Menengah Pertama Aisyiyah Fullday Wedi, Kabupaten Klaten, Provinsi Jawa Tengah. Analisis data yang digunakan dalam penelitian ini adalah analisis regresi sederhanamenggunakan program bantuan SPSS 25.0, yang hasilnya dapat dilihat padatabel sebagai berikut:

Tabel 6. Analisis Regresi Sederhana

\begin{tabular}{cccrlcc}
\hline Variabel & $\mathrm{R}$ & $\mathrm{r}^{2}$ & $\begin{array}{r}\mathrm{r} \\
\text { tabel }\end{array}$ & $\begin{array}{l}\text { Kon } \\
\mathrm{s}\end{array}$ & $\begin{array}{c}\text { Koe } \\
\mathrm{f}\end{array}$ & Keterangan \\
\hline Pembelajara & 0,69 & 0,48 & 0,213 & 9,6 & 0,41 & Adanya \\
nDaring (X) & 4 & 2 & & 1 & 3 & pengaruh \\
terhadap & & & & & & yangpositif \\
Pemahaman & & & & & & \\
Materi & & & & & & \\
Sepakbola & & & & & & \\
Mata & & & & & & \\
Pelajaran & & & & & & \\
Pendidikan & & & & & & \\
Jasmani & & & & & & \\
Olahraga & & & & & & \\
dan & & & & & \\
Kesehatan & & & & \\
(Y) & & & & & \\
\hline
\end{tabular}

\begin{tabular}{cccc}
\multicolumn{4}{c}{ Tabel 7. Uji-T } \\
\hline Variabel & $\begin{array}{c}\mathrm{t} \\
\text { tabel }\end{array}$ & $\begin{array}{c}\mathrm{t} \\
\text { hitung }\end{array}$ & Signifikansi \\
\hline $\begin{array}{c}\text { Pembelajaran Daring }(\mathrm{X}) \\
\text { terhadap Pemahaman materi } \\
\text { sepakbola Mata Pelajaran }\end{array}$ & 1,987 & 8,894 & 0,05 \\
$\begin{array}{c}\text { Pendidikan Jasmani Olahraga } \\
\text { dan Kesehatan (Y) }\end{array}$ & & & \\
\hline
\end{tabular}

Dari perhitungan data di atas menunjukkan bahwa $r$ hitung lebih besar dari $r$ tabel $(0,694$ $>0,213)$, cara lain yaitu dengan melihat harga $t$ dimana thitung $(8,894)$ lebih besar dari harga $t$ tabel $(1,987)$, sehingga hipotesis yang berbunyi: "pembelajaran daring berpengaruh terhadap pemahaman materi sepakbola Mata Pelajaran Pendidikan Jasmani Olahraga dan Kesehatan Sekolah Menengah Pertama Aisyiyah Fullday Wedi, Kabupaten Klaten, Provinsi Jawa Tengah" diterima. Koefisien determinasi $r$ square sebesar 0,482 yang berarti 4,82\% sumbangan pengaruhpembelajaran daring (X) terhadap pemahaman materi sepakbola Mata Pelajaran Pendidikan Jasmani Olahraga dan Kesehatan peserta didik (Y). Berikut merupakan garis regresi $Y=9,610+0,413 X$. Nilai konstanta adalah 9,610. Hal ini dapat diartikan jika koefisien pembelajaran daring bernilai 0 , maka pemahaman peserta didik bernilai positif yaitu 9,610. Nilai koefisien regresi variabel pembelajaran daring bernilai positif yaitu 0,413 . Hal ini dapat diartikan setiap peningkatan pembelajaran daring sebesar 1, maka pemahaman peserta didik juga akan meningkat sebesar 0,413. Berdasarkaninterpretasi koefisien korelasi ( $\mathrm{r}$ hitung), maka nilai $\mathrm{r}$ hitung sebesar 0,694 termasuk memiliki tingkat hubungan yang tinggi antara kedua variabel pada hipotesis.

Jadi dapat disimpulkan bahwa Pembelajaran Daring berpengaruh terhadap Pemahaman Materi Sepakbola Mata Pelajaran Pendidikan Jasmani Olahraga dan Kesehatan pada peserta didik Sekolah Menengah Pertama Aisyiyah Fullday Wedi Kabupaten Klaten, Provinsi Jawa Tengah. 


\section{Pembahasan}

Pada pembahasan kali ini akan dibahas dari setiap hipotesis yang akan diuji. Setelah melakukan beberapa pegujian secara umum hasil analisis penelitian ini menunjukkan bahwa terdapat pengaruh pembelajaran daringterhadap pemahaman materi sepakbola Mata Pelajaran Pendidikan Jasmani Olahraga dan Kesehatan pada peserta didik Sekolah Menengah Pertama Aisyiyah Fullday Wedi, Kabupaten Klaten, Provinsi Jawa Tengah. Hal ini dibuktikan dengan uji regresi sederhana yang menunjukkan bahwa $r$ hitung lebih besar dari $r$ tabel $(0,694>0,213)$ dan t hitung $(8,894>1,987)$. Dari hasil analisis regresi variabel $\mathrm{X}$ terhadapY diperoleh suatu persamaan $\mathrm{Y}=9,610+0,413 \mathrm{X}$. Nilai konstanta adalah 9,610. Hal ini dapat diartikan jika koefisien pembelajaran daring bernilai 0,maka pemahaman peserta didik bernilai positif yaitu 9,610 . Nilai koefisien regresi variabel pembelajaran daring bernilai positif yaitu 0,413 . Hal ini dapat diartikan setiap peningkatan pembelajaran daring sebesar 1, maka pemahaman peserta didik juga akan meningkat sebesar 0,413. Berdasarkaninterpretasi koefisien korelasi (r hitung), maka nilai $r$ hitung sebesar 0,694 termasuk memiliki tingkat hubungan yang tinggi antara kedua variabel padahipotesis.

Pembelajaran daring mempunyai manfaat yang pertama dapat membangun komunikasi dan diskusi yang sangat efisien antara guru dengan murid, kedua siswa saling berinteraksi dan berdiskusi antara siswa yang satu dengan yang lainnya tanpa melalui guru, ketiga dapat memudahkan interaksi antara siswa guru, dengan orang tua, keempat sarana yang tepat untuk ujian maupun kuis, kelima guru dapat dengan mudah memberikan materi kepada siswa berupa gambar dan video selain itu murid juga dapat mengunduh bahan ajar tersebut, keenam dapat memudahkan guru membuat soal dimana saja dan kapan saja.

Dari hasil penelitian yang dilakukan berarti pembelajaran daring membuat peserta didik lebih mudah memahami materi dan siswa lebih aktif saat pembelajaran. Hasil belajar merupakan tingkat keberhasilan yang diperoleh oleh siswa setelah mengikuti suatu kegiatan pembelajaran yang ditandai dengan nilai (Dimyati dan Mudjiono, 2009). Hal ini sesuai dengan teori bahwa model pembelajaran daring dapat meningkatkan hasilbelajar yang diperoleh oleh siswa. Hal ini dikarenakan model pembelajaran daring dapat memberikan pengalaman belajar yang lebih bermakna kepada siswa. Hasil penelitian ini menunjukkan bahwa pemahaman materi sepakbola Mata Pelajaran Pendidikan Jasmani Olahraga dan Kesehatan hanya dipengaruhi oleh 4,82\% faktor pembelajaran daring. Sementara sisanya 95,18\% dipengaruhi oleh faktor lain yang tidak dilakukan dalam penelitian ini. Penelitian ini tidak melihat faktor lain yang juga mempengaruhi pemahaman peserta didik.

\section{SIMPULAN}

Berdasarkan hasil analisis data dan pembahasan dapat diambil kesimpulan, bahwa terdapat pengaruh pembelajaran daring terhadap pemahaman materi sepakbola Mata Pelajaran Pendidikan Jasmani Olahraga dan Kesehatan pada peserta didik Sekolah Menengah Pertama Aisyiyah Fullday Wedi, Kabupaten Klaten, Provinsi Jawa Tengah. Besarnya pengaruh adalah $4,82 \%$. Hal ini dibuktikan dengan uji regresi sederhana yang menunjukkan bahwa $r$ hitung lebih besar dari $r$ tabel $(0,694>0,213)$ dan t hitung $(8,894>1,987)$. Dari hasil analisis regresi variabel $X$ terhadap $Y$ diperoleh suatu persamaan $Y=9,610+0,413 X$. Nilai konstanta adalah 9,610 . Hal ini berarti keeratan hubungan variabel X (pembelajaran daring) terhadap variabel $Y$ (pemahaman materi sepakbola Mata Pelajaran Pendidikan Jasmani Olahraga dan Kesehatan) yaitu sebesar 0,694 sehingga termasuk dalam tingkat hubungan yang kuat. Kontribusi (sumbangan) yang ada pada variabel $\mathrm{X}$ terhadap variabel $\mathrm{Y}$ sebesar 4,82\% sedangkan $95,18 \%$ dipengaruhi oleh variabel lain. Dari hasil tersebut terlihat meningkat atau menurunnya pemahaman peserta didik pada materi sepakbola Mata Pelajaran Pendidikan Jasmani Olahraga dan Kesehatan salah satunya dipengaruhi oleh pembelajaran daring di Sekolah Menengah Pertama Aisyiyah Fullday Wedi, Kabupaten Klaten, Provinsi Jawa Tengah. 
MEDIKORA, Vol. 20 No. 2 Oktober 2021 - 151

Komarudin, Rizka Prihandana Nugraha

\section{DAFTAR PUSTAKA}

Abdul Alim. (2012). Pengaruh Olahraga Terprogram terhadap Tekanan Darah dan Daya Tahan Kardiorespirasi pada Atlet Pelatda Sleman Cabang Tenis Lapangan. Jurnal Medikora. Volume VIII Nomor. 2 Hal 21-24 Tahun 2012.

Ahmad Jayul dan Edi Irwanto. (2020). Model Pembelajaran Daring Sebagai Alternatif Proses Kegiatan Belajar Pendidikan Jasmani di Tengah Pandemi Covid-19. Jurnal Pendidikan Kesehatan Rekreasi. Volume 6 Nomor 2 Hal. 190 - 199 Tahun 2020.

Bawono, Anton. (2006). Multivariate Analysis dengan SPSS. Salatiga: STAIN. Salatiga press.

Corey, Gerald. 2005. Theory and Practice of Counseling and Psychotherapy. United States of America. Brooks/Cole.

Dewi, W. A. F. (2020). Dampak Covid-19 terhadap Implementasi Pembelajaran Daring di Sekolah Dasar. Edukatif: Jurnal Ilmu Pendidikan, 2(1), 55-61.

Fehr AR, Perlman S,. (2015). Coronavirus: An Overview of Their Replication and Pathogenesis. Methods Mol Biol. 2015; 1282: 1-23.

Festiawan, R., Hooi, L. B., Widiawati, P., Yoda, I. K., Adi, S., Antoni, M. S., \& Nugroho, A. I. (2021). The Problem-Based Learning: How the effect on student critical thinking ability and learning motivation in COVID-19 pandemic?. Journal Sport Area, 6(2), 231243.

Ghozali, Imam. (2013). Aplikasi Analisis Multivariate dengan Program IBM SPSS. 21 Update PLS Regresi. Semarang: Badan Penerbit Universitas Diponegoro.

Gusdernawati, A., Mahatmasari, P. Y., Suherman, W. S., Nasrulloh, A., Lituhayu, K., \& Umam, A. K. (2021). E-learning di era pandemi covid-19: Bagaimana aksiologi hasil belajar pendidikan jasmani? Journal of Sport Education (JOPE), 3(2), 63-74. https://doi.org/10.31258/JOPE.3.2.63-74

Nasrulloh, A., Sumaryanto, S., Prasetyo, Y., Sulistiyono, S., \& Yuniana, R. (2021). Comparison of Physical Condition Profiles of Elite and Non-Elite Youth Football Players. MEDIKORA, 20(1), 73-83. https://doi.org/10.21831/MEDIKORA.V20I1.39547

Huang C, wang Y, Li X, ren L, Zhao J, Zang Li, Fan G, etc. (2020). Clinical features of patients infected with 2019 novel coronavirus in Wuhan, China. The Lancet. 24 January 2020.

Komarudin. (2013). Dasar Gerak Sepakbola. Yogyakarta: FIK UNY Press.

Lizha Dzalila Q. A, Annisa Ananda, dan Saifuddin Zuhri. (2020). Pengaruh Pembelajaran Daring Pada Masa Pandemi Covid - 19 Terhadap Tingkat Pemahaman Belajar Mahasiswa. Jurnal Signal Volume 8 Nomor 2 Hal 89 - 214 Tahun 2020.

Mulyadi, Mohammad. (2011). Penelitian Kualitatif dan Kuantitatif Serta Pemikiran Dasar Menggabungkannya. Jurnal Studi Komunikasi dan Media.Volume 15 Nomor 1. Tahun 2011. 
Nakayama, M., Yamamoto, H., and Santiago, R. (2007). The Impact of Learner Characteristics on Learning Performance in Hybrid Courses among Japanese Students. Electronic Journal e-Learning Vol.5(3).195-206.

Menteri Pendidikan. (2020). Surat Edaran Nomor 3 Tahun 2020 Tenang Pelaksanaan Pendidikan dalam Masa Darurat CoronaVirus (COVID-19).

Mulyasa, E. (2013). Pengembangan dan Implementasi Kurikulum 2013. Bandung : Remaja Rosdakarya.

Permendikbud No. 22 Tahun 2016 Tentang Pelaksanaan Pembelajaran.

Purwanto, A., Pramono, R., Asbari, M., Santoso, P. B., Wijayanti, L. M., Choi, C. H., \& Putri, R. S. (2020). Studi Eksploratif Dampak Pandemi COVID-19 Terhadap Proses Pembelajaran Online di Sekolah Dasar. EduPsyCouns: Journal of Education, Psychology and $\quad$ Counseling, 2(1), 1-12. journal.id/Edupsycouns/article/view/397.

Putra, Angga Narendah. (2020). Implementasi Pembelajaran PJOK Pada Masa Pandemi Covid - 19 di SD Negeri Se - Kecamatan Lendah Kabupaten Kulon Progo Daerah Istimewa Yogyakarta. Skripsi. Program Studi Pendidikan Guru Sekolah Penjas Fakultas Ilmu Keolahragaan Universitas Negeri Yogyakarta Tahun 2020.

Rohmah, Lailatu. (2016). Konsep E - Learning Dan Aplikasinya Pada Lembaga Pendidikan Islam. Jurnal Studi Islam. Volume 3 Nomor 2 Tahun 2016.

Ross, E. W.ed. (2006). The Social Studies Curriculum. Purposes. Problems and Possibilities. $3^{\text {rd }}$ Edition. Albany New York: State University Of New York Press.h 22.

Rusman, dkk. (2011). Pembelajaran Berbasis Teknologi Informasi dan. Komunikasi : Mengembangkan Profesionalisme Guru. Jakarta : Rajawali Pers.

Saryono \& Rithaudin, A . (2011). Meta Analisis Pengaruh Pembelajaran Pendekatan Taktik (TGFU) Terhadap Pengembangan Aspek Kognitif Siswa Pendidikan Jasmani. Jurnal Pendidikan Jasmani Indonesia. Volume 8 Nomor 2 Tahun 2011.

Sudjana. (2003). Teknik Analisis Regresi dan Korelasi. Bandung : Tarsito.

Sugiyono. (2018). Metode Penelitian Kuantitatif. Bandung: Alfabeta.

Suherman, Maman dan Herlina. (2020). Potensi Pembelajaran Pendidikan Jasmani, Olahraga dan Kesehatan (PJOK) di Tengah Pandemi Corona Virus Disease (Covid - 19) di Sekolah Dasar. Tadulako Journal Sport Sciences and Physical Education. Volume 8 Nomor 1 Tahun 2020.

Undang - Undang No 20 Tahun 2003 tentang Sistem Pendidikan Nasional Pendidikan.

Yaumi, Muhammad. (2013). Prinsip-Prinsip Desain Pembelajaran. Jakarta: Kencana Media Grup. 